\title{
Mitochondrial genomes of three Tetrigoidea species and phylogeny of Tetrigoidea
}

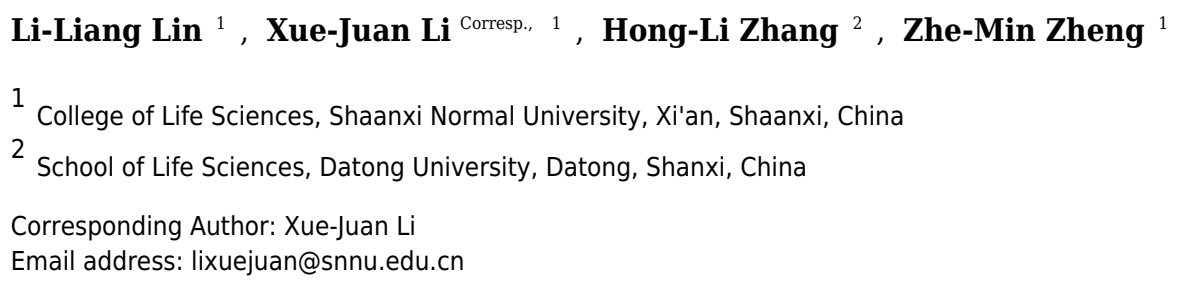

The mitochondrial genomes (mitogenomes) of Formosatettix qinlingensis, Coptotettix longjiangensis and Thoradonta obtusilobata (Orthoptera: Caelifera: Tetrigoidea) were sequenced in this study, and almost the entire mitogenomes of these species were determined. The mitogenome sequences obtained for the three species were 15,180 , 14,495 and $14,538 \mathrm{bp}$ in length, respectively, and each sequence included 13 proteincoding genes (PCGs), partial sequences of rRNA genes (rRNAs), tRNA genes (tRNAs) and a $A+T$-rich region. The order and orientation of the gene arrangement pattern were identical to that of most Tetrigoidea species. Some conserved spacer sequences between trnS(UCN) and nadl were useful to identify Tetrigoidea and Acridoidea. The Ka/Ks value of atp8 between Trachytettix bufo and other four Tetrigoidea species indicated that some varied sites in this gene might be related with the evolution of $T$. bufo. The three Tetrigoidea species were compared with other Caelifera. At the superfamily level, conserved sequences were observed in intergenic spacers, which can be used for superfamily level identification between Tetrigoidea and Acridoidea. Furthermore, a phylogenomic analysis was conducted based on the concatenated data sets from mitogenome sequences of 24 species of Orthoptera in the superorders Caelifera and Ensifera. Both maximum likelihood and bayesian inference analyses strongly supported Acridoidea and Tetrigoidea as forming monophyletic groups. The relationships among six Tetrigoidea species were $((()($ Tetrix japonica, Alulatettix yunnanensis), Formosatettix qinlingensis), Coptotettix longjiangensis), Trachytettix bufo), Thoradonta obtusilobata). 
1 Mitochondrial genomes of three Tetrigoidea species and phylogeny of Tetrigoidea

2 Liliang Lin ${ }^{1}$, Xuejuan Li ${ }^{1 *}$, Hongli Zhang ${ }^{2}$, Zhemin Zheng ${ }^{1}$

3

41 College of Life Sciences, Shaanxi Normal University, Xi'an 710062, China;

52 School of Life Sciences, Datong University, Datong 037009, China

$6 \quad{ }^{*}$ Corresponding author: Xuejuan Li, E-mail: lixuejuan@snnu.edu.cn 


\section{ABSTRACT}

The mitochondrial genomes (mitogenomes) of Formosatettix qinlingensis, Coptotettix longjiangensis and Thoradonta obtusilobata (Orthoptera: Caelifera: Tetrigoidea) were sequenced in this study, and almost the entire mitogenomes of these species were determined. The mitogenome sequences obtained for the three species were 15,180,14,495 and 14,538 bp in length, respectively, and each sequence included 13 proteincoding genes (PCGs), partial sequences of rRNA genes (rRNAs), tRNA genes (tRNAs) and a A+T-rich region. The order and orientation of the gene arrangement pattern were identical to that of most Tetrigoidea species. Some conserved spacer sequences between $\operatorname{trnS}(\mathrm{UCN})$ and nad1 were useful to identify Tetrigoidea and Acridoidea. The $\mathrm{Ka} / \mathrm{Ks}$ value of atp8 between Trachytettix bufo and other four Tetrigoidea species indicated that some varied sites in this gene might be related with the evolution of $T$. bufo. The three Tetrigoidea species were compared with other Caelifera. At the superfamily level, conserved sequences were observed in intergenic spacers, which can be used for superfamily level identification between Tetrigoidea and Acridoidea. Furthermore, a phylogenomic analysis was conducted based on the concatenated data sets from mitogenome sequences of 24 species of Orthoptera in the superorders Caelifera and Ensifera. Both maximum likelihood and bayesian inference analyses strongly supported Acridoidea and Tetrigoidea as forming monophyletic groups. The relationships among six Tetrigoidea species were (((((Tetrix japonica, Alulatettix yunnanensis), Formosatettix qinlingensis), Coptotettix longjiangensis), Trachytettix bufo), Thoradonta obtusilobata).

\section{INTRODUCTION}

Tetrigoidea is a superfamily of Caelifera in Orthoptera and is regarded as a primitive taxon of Caelifera (Cao and Zheng, 2011). This superfamily contains approximately 274 genera and 2356 species, according to the OSF website (Orthoptera Species File, http://orthoptera.speciesfile.org) (Eades et al., 2014). All species in Tetrigoidea are in the family Tetrigidae, which contains nine subfamilies (Batrachideinae, Cladonotinae, Cleostratinae, Discotettiginae, Lophotettiginae, Metrodorinae, Scelimeninae, Tetriginae and Tripetalocerinae)(Eades et al., 2014). Based on the morphological features of antennae shape and the frontal ridge, anterior margin and lateral angle of the pronotum, the Tetrigoidea is divided into seven families by most Chinese taxonomists, i.e., Batrachididae, Cladonotidae, Discotettigidae, Metrodoridae, Scelimenidae, Tetrigidae and Tripetaloceridae (Zheng, 2005; Deng et al., 2007).

Because of their small size and minor importance as agricultural pests, this group has been of little concern and the focus of few studies. The study of Tetrigoidea focused primarily on behaviour, morphology, anatomy and cytology before the 1990s, and included bioecological observations (Paranjape and Bhalerao, 1985) and karyology (Warchałowska-Śliwa and Maryańska-Nadachowska, 1989; Maryańska-Nadachowska and Warchałowska-Śliwa, 1991; del Cerro et al., 1997; Ma and Zheng, 1994; Ma and Guo, 1994). Research on the molecular systematics of Tetrigoidea gradually appeared later, with most of the studies focusing only on single genes. For example, the phylogenetic results of Flook and Rowell (1997a, 1997b) support the monophyly of Tetrigoidea and a close relation between Tetrigoidea and Tridactyloidea. In a study of the phylogeny of Tetrigoidea, Jiang (2000) showed that Scelimenidae was sister group to all other Tetrigoidea of the sampling, and Tetrigidae located at the end of the phylogeny. However, according to the research of Chen (2005) and Yao (2008), Batrachididae was located at a more basal position and sistered to all other Tetrigoidea. 
Animal mitogenome sequencing has exploded in recent years, and over 40,000 mitogenomes are avalialbe in the NCBI database (Tan et al., 2017). The insect mitogenome is typically a small, double-stranded circular molecule that ranges in size from 14 to $19 \mathrm{~kb}$ and encodes 37 genes (Kim et al., 2005). The mitogenome is one of the most extensively studied genomic systems and a widely used molecular component in the phylogenetic analysis of insects (Cameron, 2014), such as Tarragoilus diuturnus (Zhou et al., 2014) and Lerema accius (Cong and Grishin, 2016).

Tetrigoidea is an important group in the phylogenetic and systemic studies of Caelifera; however, few complete mitogenomes were found in the GenBank database. Thus, currently, the phylogeny of Tetrigoidea is almost completely unknown (Song et al., 2015). For further study of the phylogenetic relationships among Tetrigoidea, the entire mitogenomes of Formosatettix qinlingensis, Coptotettix longjiangensis and Thoradonta obtusilobata were determined in this study. The phylogenetic analysis based on mitogenome data will provide a new insight for better understanding the phylogenetic relationship of Caelifera as well as Tetrigoidea.

\section{MATERIALS AND METHODS}

\section{Sample collection and DNA extraction}

Specimens of $F$. qinlingensis were collected in Shaanxi, China, those of $C$. longjiangensis in the Guangxi Zhuang Autonomous Region, China, and those of T. obtusilobata in Guizhou, China. Insects were preserved in $100 \%$ ethanol and stored at $4{ }^{\circ} \mathrm{C}$. The total genomic DNA was extracted using the standard phenol/chloroform method (Sambrook and Russell, 2001).

\section{PCR amplification and sequencing by primer walking}

Ten primary pairs of primers (Table S1) were used to amplify contiguous and overlapping fragments of the mitogenomes of $F$. qinlingensis, $C$. longjiangensis and $T$. obtusilobata, based on other published primer pairs (Zhou, 2008; Simon et al., 2006). PCR was performed in a total volume of $25 \mu \mathrm{L}$ containing $12.5 \mu \mathrm{L}$ of rTaq mix (TaKaRa, Dalian, China), $9.5 \mu \mathrm{L}$ of $\mathrm{ddH}_{2} \mathrm{O}, 1 \mu \mathrm{L}$ of each primer $(10 \mu \mathrm{mol})$, and $1 \mu \mathrm{L}$ of template DNA. The amplifications were performed under the following conditions: predenaturation at $96{ }^{\circ} \mathrm{C}$ for $2 \mathrm{~min}$ followed by 40 cycles of $96^{\circ} \mathrm{C}$ for $20 \mathrm{~s}, 50.4{ }^{\circ} \mathrm{C}$ for $90 \mathrm{~s}$ and $68{ }^{\circ} \mathrm{C}$ for $4 \mathrm{~min}$ and a final extension at $72{ }^{\circ} \mathrm{C}$ for 7 min. PCR products were sequenced by Beijing Huada Gene Technology Co., LTD.

\section{Sequence assembly, annotation and analysis}

The mitogenome sequences of $F$. qinlingensis, $C$. longjiangensis and $T$. obtusilobata were assembled using the Staden package 1.7.0 (Staden et al., 2000). Most of the transfer RNAs were identified by tRNAscanSE 1.21 (Lowe and Eddy, 1997), and the other genes were determined by comparison with $T$. japonica (GenBank accession number JQ340002). The secondary structures of rRNA were inferred by comparison with those of Pedopodisma emiensis (Zeng, 2014) and Gomphocerus sibiricus (Zhang, 2013).

The nucleotide base compositions were calculated with Geneious 10.1.3 (Kearse et al., 2012), while the relative synonymous codon usage (RSCU) values for PCGs were calculated using MEGA 6.0 (Tamura et al., 2013). Composition skew analysis was conducted with formulas AT-skew $=[\mathrm{A}-\mathrm{T}] /[\mathrm{A}+\mathrm{T}]$ and GCskew $=[\mathrm{G}-\mathrm{C}] /[\mathrm{G}+\mathrm{C}]$ (Perna and Kocher, 1995). The nonsynonymous substitution rate (Ka) and the synonymous substitution rate (Ks) were analyzed in DnaSP5.1 (Librado and Rozas, 2009).

\section{Phylogenetic analyses}

In this study, the complete mitogenomes of 21 members of Caelifera, including three newly determined sequences of $F$. qinlingensis, $C$. longjiangensis and $T$. obtusilobata were used in the phylogenetic analysis 
(Table S2). Three species of Ensifera were used as the out-groups (Table S2). Thirteen protein-coding genes (PCG) and two rRNA genes were used for the construction of phylogenetic trees. All PCGs were aligned at the amino acid level using the default settings in MEGA 6.0 (Tamura et al., 2013), and the alignments were back translated to the corresponding nucleotide sequences. Because of high variability, the stop codons in PCGs were excluded in the alignment (Zhang et al., 2014; Shuang-Shuang et al., 2014). Two rRNA genes were aligned using Clustal X1.83 (Thompson et al., 1997), respectively. Finally, a PCG12 data set of 7580 bp containing the first and second codon sites of 13 PCGs, a PCG123RY data set of 11,370 bp containing 13 PCGs with the third codon sites employing RY-coding strategy, a PCG12rRNA data set of 9950 bp containing the first and second codon sites of 13 PCGs and two rRNA genes, and a PCG123RYrRNA data set of 13,740 bp containing 13 PCGs with the third codon sites employing RY-coding strategy and two rRNA genes were used for the phylogenetic analyses. PartitionFinder v1.1.1 (Lanfear et al., 2012) was used to search the optimal partitions and best models, with the "unlinked" branch lengths, "BIC" model selection, and "greedy" algorithm (Table 1).

The phylogenies were determined using both maximum likelihood (ML) and Bayesian inference (BI) methods. The ML analysis was performed using the program RAxML version 7.0.3 (Stamatakis 2006), and the optimal partitions partitions and best models were selected by using PartitionFinder v1.1.1 (Lanfear et al., 2012). A bootstrap analysis was performed with 1000 replicates. The BI analysis was performed using MrBayes version 3.1.2 (Ronquist and Huelsenbeck, 2003), and also employing the optimal partitions partitions and best models selected by PartitionFinder v1.1.1 (Lanfear et al., 2012). According to Markov Chain Monte Carlo analysis, four chains (one cold and three heated chains) were set to run simultaneously for 1,000,000 generations. Each set was sampled every 100 generations with a burn-in of $25 \%$, and the remaining samples were used to obtain the consensus tree. The effective sample size values were analyzed by Tracer v1.5 (Rambaut and Drummond, 2004), with ESS values greater than 200.

\section{RESULTS AND DISCUSSION}

\section{Mitochondrial genomic structure}

The size of the mitogenome sequence obtained from $F$. qinlingensis, $C$. longjiangensis and $T$. obtusilobata was 15,180, 14,495 and 14,538 bp, respectively (Table 2). The three mitogenomes were deposited in the GenBank database under accession numbers KY798412 (F. qinlingensis), KY798413 (C. longjiangensis) and KY798414 (T. obtusilobata). The gene composition, order, and orientation of all three mitogenomes were the same as those of the mitogenomes of other Tetrigoidea species, such as T. japonica (JQ340002), and each sequence included 13 protein-coding genes (PCGs), partial sequences of rRNA genes (rRNAs), tRNA genes (tRNAs) and a A+T-rich region (Table 2, Fig. 1). As shown in other Tetrigoidea species, transcribed from the light strand were two rRNAs, four PCGs and eight tRNAs (Table 2). The A+T contents were $75.6 \%, 73.1 \%$ and $71.8 \%$ in the mitogenomes of the Tetrigoidea species $F$. qinlingensis, $C$. longjiangensis and T. obtusilobata, respectively.

\section{Nucleotide composition and skew}

A comparative analysis of $\mathrm{A}+\mathrm{T}$ content vs AT-skew and $\mathrm{G}+\mathrm{C}$ content vs GC-skew within Caelifera mitogenomes is shown in Fig. 2. The approximately positive correlation were found between $\mathrm{A}+\mathrm{T}$ content and AT-skew, and as well as between $\mathrm{G}+\mathrm{C}$ content and GC-skew. The trends of increased A+T content and ATskew were roughly Tridactyloidea $<$ Eumastacoidea $<$ Acridoidea/Tetrigoidea, while the increased $\mathrm{G}+\mathrm{C}$ content 
and GC-skew were roughly Acridoidea/Tetrigoidea< $<$ Tridactyloidea.

The average AT-skew of Caelifera mitogenomes was 0.15, ranging from 0.01 in Ellipes minuta to 0.22 in C. longjiangensis (Table S3). The average GC-skew of mitogenomes was -0.19 , ranging from -0.30 in $E$. minuta to -0.11 in Pielomastax zhengi (Table S3). The Tridactyloidea had lower A+T content and A-skew, higher $\mathrm{G}+\mathrm{C}$ content and $\mathrm{C}$-skew compared with other superfamily in Caelifera.

\section{Spacers and overlaps}

A total of 7 intergenic spacers ranging from 1 to $12 \mathrm{bp}$ were found in the mitogenome of $F$. qinlingensis. Among these spacers, the longest noncoding region (12 bp) was found between $\operatorname{trnS}(\mathrm{UCN})$ and nad1. Overlapping regions ranging from 1 to $8 \mathrm{bp}$ occurred in the $F$. qinlingensis mitogenome, such as the $8 \mathrm{bp}$ overlap between trnW and trnC. Most of the intergenic spacers and overlapping regions in $F$. qinlingensis were similar to those in the mitogenomes of the other two species of Tetrigoidea. However, a long intergenic spacer occurred between trnS(UCN) and nad1 in C. longjiangensis (131 bp) and T. obtusilobata (399 bp). Long noncoding regions between trnS(UCN) and nad1 also occur in the insect orders Hymenoptera, Coleoptera and Hemiptera, and in other orthopterans, with a length from 40 to $300 \mathrm{bp}$. For example, Xyleus modestus (Orthoptera: Caelifera) contains a noncoding region (259 bp) between trnS(UCN) and nad1 (Sheffield et al., 2010). Moreover, some conserved sequences occur, such as ATACTAA in Lepidoptera, TACTA in Coleoptera, and THACWW in Hymenoptera (Wei, 2009). However, although the sequences in Orthoptera had low similarity, sequence conservation was observed at the superfamily level (Fig. 3). Sequences (TTCTAWTTTT) in Tetrigoidea and sequences (TTCTNRAAA) in Acridoidea were conserved; therefore, these conserved sequences might be useful for the identification of Tetrigoidea and Acridoidea.

\section{Protein-coding genes}

In $F$. qinlingensis, $C$. longjiangensis and T. obtusilobata, the A+T content of PCGs was $74.7 \%, 72.0 \%$ and $70.5 \%$, respectively. For each PCG of the three Tetrigoidea mitogenomes, the A+T contents of atp 8 and nad6 were much higher and those of COX genes in all three species lower than those of the other genes (Fig. S1), which are similar results to those found by Zhang et al. (2013b). Four PCGs (nad5, nad4, nad4L and nad1) coded by the N-strand had a T-skewed value, whereas each PCG in the J-strand was C-skewed, and each PCG in the N-strand was G-skewed (Fig. S1), which are results similar to those for Gomphocerinae mitogenomes (Zhang et al., 2013b).

For the initial and termination codons, the most common start codon was ATG. Start codons GTG, ATT, ATC, ATA, GTA and ACA also occurred in the Tetrigoidea species, with some of them conserved, such as ATC in cox1. The same use of ATC in cox1 is found in other Caelifera, such as Calliptamus italicus (EU938373), Oxya chinensis (EF437157), Prumna arctica (GU294758) and Traulia szetschuanensis (EU914849) of Acridoidea, P. zhengi (JF411955) of Eumastacoidea, and A. yunnanensis (JQ272702) and T. japonica (JQ340002) of Tetrigoidea.

For all three Tetrigoidea species, stop codon usage was consistent in 11 PCGs (nad2, cox2, atp8, atp6, cox3, nad3, nad5, nad4, nad4L, nad6 and nad1). Cox3 and nad5 were terminated with the incomplete stop codon $\mathrm{T}$ in the three Tetrigoidea species. The terminal $\mathrm{T}$ serves as a stop signal after it is completed to UAA via post-transcriptional polyadenylation (Ojala et al., 1981).

The relative synonymous codon usage of Caelifera was analyzed. The use of the anticodons NNA and NNU was relatively frequent, while NNG and NNC was lower (Table S4). This result revealed the preference for $\mathrm{A}$ or $\mathrm{T}$ in the third position, which was similar to the results of whiteflies (Chen et al., 2016). Mitogenome 
encoded 22 tRNA genes, which were used to synthesis 20 amino acids. Some mostly used synonymous codons of PCGs did not correspond to the tRNA anticodons of mitogenomes. For example, UUU is the mostly used synonymous codon of Phe $(\mathrm{F})$ (Table S4), while anticodon of trnF in the mitogenomes is UUC (Figure S4). This result shows that the protein synthesis of mitogenomes not only depends on mitochondria encoded tRNAs, but also needs nuclear encoded tRNAs.

The average ratio of $\mathrm{Ka} / \mathrm{Ks}$ was calculated for each PCG of six Tetrigidae mitogenomes. The results showed that atp8 had the highest evolutionary rate, while cox1 was the lowest (Table S5). The average ratios of $\mathrm{Ka} / \mathrm{Ks}$ for each PCG were all below 1 (Table S5), indicating the existence of purifying selection. A roughly negative correlation was observed between the average ratio of $\mathrm{Ka} / \mathrm{Ks}$ and the $\mathrm{G}+\mathrm{C}$ content of each PCG (Table S5), which was also found in true bug mitogenomes (Li et al., 2012). The evolutionary patterns of mitochondrial genes were probably caused by the varied $\mathrm{G}+\mathrm{C}$ content (Hua et al., 2008). Furthermore, the ratios of $\mathrm{Ka} / \mathrm{Ks}$ for atp8 gene were above 1 in some pairwise comparison (Fig. 4), indicating under positive selection. The varied sites of atp8 gene might be associated with the evolution of $T$. bufo (Fig. 5).

\section{Ribosomal and transfer RNA genes}

As in most insect mitogenomes, two rRNA genes (rrnL and $\mathrm{rnS}$ ) occurred in the three Tetrigoidea mitogenomes between $\operatorname{trnL}$ (cun) and the A+T-rich region, separated by trnV. The lengths of $\operatorname{rrnS}$ and $\operatorname{rrnL}$ determined in $F$. qinlingensis were 781 and $1292 \mathrm{bp}$, respectively, and the A+T content of rrnS and rnL was $76.7 \%$ and $79.3 \%$, respectively.

The overall $\mathrm{rnS}$ structure of $F$. qinlingensis included three domains (Fig. S2), which were identical with those predicted for other Caelifera species, such as G. sibiricus (Zhang et al., 2013b). The secondary structure of rnL in $F$. qinlingensis contained six domains with domain III degenerated to a single strand as one bond (Fig. S3), which is a structure similar to that found in the study of Zhang et al. (2013b). The percentage of conserved sites in the six domains among the three Tetrigoidea species showed that more conserved sites were in domains IV, V and VI than in other domains, whereas domain III had more variable sites.

A total of 22 tRNAs were found interspersed in the mitogenomes of $F$. qinlingensis and $C$. longjiangensis, which ranged in size from $54 \mathrm{bp}$ (trnI) to $72 \mathrm{bp}(\operatorname{trnV})$. Both trnL and trnS had two copies in the mitogenomes. Most of the tRNAs could be folded into the canonical cloverleaf secondary structure, except for trnS(agn) (Fig. S4). The trnS(agn) lacked the DHU arm in the three Tetrigoidea mitogenomes, which is a feature commonly observed in other Caelifera species (Zhao et al., 2010; Liu and Huang, 2010). Twenty-two non-Watson-Crick pairings were identified in tRNA genes of the $F$. qinlingensis mitogenome, including 18 G$\mathrm{U}$ mismatches. Most of these G-U pairs were found in tRNAs on the N-strand. By contrast, in the study of Asakawa et al. (1991), G-U pairs are found more frequently in tRNAs of the J-strand in mitogenomes of the various animals they examined. Two A-G pairs were predicted in the acceptor arm of trnW and trnR; one A-A pair was predicted in the acceptor arm of trnQ; and one C-U pair was predicted in the T $\psi \mathrm{C}$ arm of trnH (Fig. S4).

\section{A+T-rich region}

A $600 \mathrm{bp} \mathrm{A+T-rich} \mathrm{region} \mathrm{was} \mathrm{observed} \mathrm{between} \operatorname{rrnS}$ and $\operatorname{trnI}$ in the mitogenome of $F$. qinlingensis, which was composed of $80.8 \% \mathrm{~A}+\mathrm{T}$. The high mutation rate of this region might be related to the high $\mathrm{A}+\mathrm{T}$ content and low selection pressure (Yang et al., 2011). F. qinlingensis had a larger A+T-rich region than that of other species of Tetrigoidea, e.g., $460 \mathrm{bp}$ in A. yunnanensis (JQ272702) and $531 \mathrm{bp}$ in T. japonica (JQ340002). Conserved or variable sections are not observed in the A+T-rich regions of insects; whereas 
tandem repetitions and conserved structural elements have been observed (Zhang et al., 1995; Zhang and Hewitt, 1997). The A+T-rich region of $F$. qinlingensis contained tandem repeated sequences, and the repeats with (AATAATAAAAAAA)n $(\mathrm{n}=3.1)$ were found at the 5' end of the A+T-rich region (nt 30-71), with more A nucleotides.

\section{Phylogenetic analyses}

The phylogenetic trees resulting from the PCG-ML and PCG-BI analyses were consistent, except for Myrmecophilus manni (Fig. 6 and S5). The ML and BI topologies of mtDNA generated similar tree topology, except for Pseudotmethis rubimarginis, Filchnerella helanshanensis, Acrida cinerea and Locusta migratoria (Fig. 6 and S5).

The results of the phylogenetic relationships among the major superfamilies were largely congruent with previous studies (Flook et al., 1995; Leavitt et al., 2013; Song et al., 2015). The relationships among four superfamilies of Caelifera were (((Acridoidea+Eumastacoidea)+Tetrigoidea)+Tridactyloidea), which is similar to the superfamily relationships determined in previous studies that used morphological and molecular evidence (Flook et al., 1995; Leavitt et al., 2013; Song et al., 2015). In this study, Tridactyloidea was the sister group to Caelifera, and Tetrigoidea was located at a relatively basal position in Caelifera compared with Acridoidea and Eumastacoidea, which are relations consistent with those in the studies of Flook and Rowell (1997b) and Song et al. (2015). The results strongly supported the monophyly of Tetriginae, sister to the Cladonotinae, whereas Scelimeninae was in the basal position. The relationships among Tetrididae were $(((($ Alulatettix yunnanensis + Tetrix japonica $)+$ Formosatettix qinlingensis $)+$ Coptotettix longiangensis $)+$ Trachytettix bufo) + Thoradonta obtusilobata).

In this study, Acrididae was the sister group of Pyrgomorphidae in Acridoidea. The phylogenetic relationships of subfamilies in $(((($ Gomphocerinae + Oedipodinae $)+(($ Calliptaminae + Catantopinae $)+($ Oxyinae + Melanoplinae $)))+($ Acridinae $+O$ edipodinae) $)+$ Thrinchinae). However, the phylogenetic relationships within Acrididae obtained in this study contained some differences with other studies (Zhang et al., 2013a), such as a clade including $A$. cinerea and $L$. migratoria, which might be caused by different sampling approaches. Apart from different sampling approaches, hybridization might be a major reason for the difference, as hybridization has been observed and described in a number of acridoid species (Gottsberger, 2007; Hochkirch and Lemke, 2011; Rohde et al., 2015).

\section{CONCLUSIONS}

The mitogenomes of Formosatettix qinlingensis, Coptotettix longjiangensis and Thoradonta obtusilobata were sequenced in this study. The analyses of mitochondrial features showed that conserved sequences were observed in intergenic spacers at the superfamily level. The phylogenetic results support the relationship of (((((Tetrix japonica, Alulatettix yunnanensis), Formosatettix qinlingensis), Coptotettix longjiangensis), Trachytettix bufo), Thoradonta obtusilobata) in Tetrigoidea.

\section{ADDITIONAL INFORMATION AND DECLARATIONS}

\section{DNA Deposition}


254 The following information was supplied regarding the deposition of DNA sequences:

255 The newly described mitogenomes have being submitted to GenBank:

256 KY798412 (Formosatettix qinlingensis), KY798413 (Coptotettix longjiangensis) and KY798414 (Thoradonta

257 obtusilobata).

258

259

\section{Data Availability}

260 The following information was supplied regarding data availability:

261 GenBank: KY798412, KY798413 and KY798414. 
263 Tables

264 Table 1 The optimal partitions and best models for different data sets selected by using PartitionFinder

265 v1.1.1. Note: pos1: the first codon site of each PCG, pos2: the second codon site of each PCG, pos3: the third 266 codon site of each PCG.

267 Table 2 Annotation of the mitochondrial genomes of Formosatettix qinlingensis (F. q), Coptotettix 268 longjiangensis (C. I) and Thoradonta obtusilobata (T. o).

Figures

Figure 1 Mitochondrial map of three Tetrigoidea species (Formosatettix qinlingensis, Coptotettix longjiangensis and Thoradonta obtusilobata). Note: * means partial or not sequenced genes. Figure 2 The A+T content vs AT-skew and G+C content vs GC-skew in Caelifera mitogenomes. Figure 3 Alignments of the intergenic spacer between $\operatorname{trnS}(\mathrm{UCN})$ and nad1 genes in caeliferan mitogenomes. Figure 4 The $\mathrm{Ka} / \mathrm{Ks}$ values of atp8 gene with paired comparison in six Tetrigidae mitogenomes. Note: A.y: Alulatettix yunnanensis, T.j: Tetrix japonica, T.b: Trachytettix bufo, F.q: Formosatettix qinlingensis, C.1: Coptotettix longjiangensis, T.o: Thoradonta obtusilobata.

Figure 5 The varied amino acid and corresponding nucleotide sequences of atp8 gene in five Tetrigidae mitogenomes.

Figure 6 Phylogenetic reconstructions of some Caelifera species based on different datasets and methods. Notes: Node supports from left to right above lines are the results of ML trees of PCG12, PCG123RY, PCG12rRNA and PCG123RYrRNA datasets, under lines are BI trees of PCG12, PCG123RY, 


\section{Supporting Information}

Table S1 Primer pairs used in PCR amplification of the mitogenomes of Formosatettix qinlingensis, Coptotettix longjiangensis and Thoradonta obtusilobata.

Table S2 Taxon samples, mitochondrial genome sequence accession numbers, and representative families and subfamilies following the classification of Otte.

Table $\mathbf{S 3}$ The values of $\mathbf{A}+\mathbf{T}$ content, $\mathbf{A T}$-skew, $\mathbf{G}+\mathbf{C}$ content and GC-skew in 21 Caelifera mitogenomes. Table S4 The relative synonymous codon usage (RSCU) of 21 Caelifera mitochondrial PCGs. Note: The highest codon usages within relative synonymous codons are in bold, with codons corresponded to tRNA anticodons written in green, and not corresponded to tRNA anticodons in red.

Table S5 The average ratio of $\mathrm{Ka} / \mathrm{Ks}$ and $\mathrm{G}+\mathrm{C}$ content for each PCG of six Tetrigidae mitogenomes.

Figure S1 Nucleotide composition of 13 PCGs from three Tetrigoidea mitogenomes. Notes: Formosatettix qinlingensis (F. q), Coptotettix longjiangensis (C. 1) and Thoradonta obtusilobata (T. o).

Figure S2 Secondary structure of Formosatettix qinlingensis rrnS. Notes: Each helix is numbered progressively from the 5' to the 3' end. Domains are labelled with Roman numerals.

Figure S3 Secondary structure of Formosatettix qinlingensis rrnL. Notes: Each helix is numbered progressively from the 5' to the 3' end. Domains are labelled with Roman numerals. Single variable sites from two species are labelled in different colours (Coptotettix longjiangensis: red; Thoradonta obtusilobata: green). Figure S4 Secondary structure of most Formosatettix qinlingensis tRNAs. Notes: Single variable sites from two species are labelled in different colours (Coptotettix longjiangensis: red; Thoradonta obtusilobata: green). Figure S5 Phylogenetic relationships corresponding to Figure 6. Notes: (A) PCG12-ML tree, (B) PCG12BI tree, (C) PCG123RY-ML tree, (D) PCG123RY-BI tree, (E) PCG12rRNA-ML tree, (F) PCG12 rRNA-BI tree , (G) PCG123RYrRNA-ML tree, (H) PCG123RYrRNA-BI tree. 


\section{REFERENCES}

Asakawa S, Kumazawa Y, Araki T, Himeno H, Miura K, Watanabe K. 1991. Strand specific nucleotide composition bias in Echinoderm and vertebrate mitochondrial genome. Journal of Molecular Evolution 32:511-520.

Cameron SL. 2014. Insect mitochondrial genomics: implications for evolution and phylogeny. Annual Review of Entomology 59:95-117.

Cao CQ, Zheng ZM. 2011. A survey of Tetrigoidea from Emeishan, Sichuan, China (Orthoptera) with descriptions of two new new species. Acta Zootaxonomica Sinica 36:737- 741.

Chen AH. 2005. Phylogentic relationship research of Tetrigoidea in China. M. Sc. Thesis, Nanjing Normal University.

Chen ZT, Mu LX, Wang JR, Du YZ. 2016. Complete mitochondrial genome of the citrus spiny Whitefly Aleurocanthus spiniferus (Quaintance) (Hemiptera: Aleyrodidae): Implications for the phylogeny of whiteflies. PLoS One 11:e0161385.

Cong Q, Grishin NV. 2016. The complete mitochondrial genome of Lerema accius and its phylogenetic implications. PeerJ 4:e1546.

del Cerro AL, Jones GH, Santos JL. 1997. Chiasma localization and incomplete synapsis in two species of Tetrigidae (Orthoptera). Chromosome Research 5:69-71.

Deng WA, Zheng ZM, Wei SZ. 2007. Fauna of Tetrigoidea from Yunnan and Guangxi. Nanning: Science and Technology Press pp.1-458.

Eades DC, Otte D, Cigliano MM, Braun H. 2014. Orthoptera Species File. Version 5.0/5.0 [retrieved at April 2017]. Available from: http://Orthoptera.SpeciesFile.org.

Flook PK, Rowell CHF. 1997a. The effectiveness of mitochondrial rRNA gene sequences for the reconstruction of the phylogeny of an insect order (Orthoptera). Molecular Phylogenetics and Evolution 8:177-192.

Flook PK, Rowell CHF. 1997b. The phylogeny of the caelifera (Insecta, Orthoptera) as deduced from mtrRNA gene sequences. Molecular Phylogenetics and Evolution 8:89-103.

Flook PK, Rowell CHF, Gellissen G. 1995. Homoplastic rearrangements of insect mitochondrial transferRNA genes. Naturwissenschaften 82:336-337.

Gottsberger B. 2007. Interspecific hybridization between the grasshoppers Chorthippus biguttulus and $C$. brunneus (Acrididae; Gomphocerinae). Dissertation, University Erlangen-Nürnberg. Available from: https://opus4.kobv.de/opus4-fau/frontdoor/index/index/year/2008/docId/596.

Hochkirch A, Lemke I. 2011. Asymmetric mate choice, hybridization, and hybrid fitness in two sympatric grasshopper species. Behavioral Ecology and Sociobiology 65:1637-1645.

Hua JM, Li M, Dong PZ, Cui Y, Xie Q, Bu WJ. 2008. Comparative and phylogenomic studies on the mitochondrial genomes of Pentatomomorpha (Insecta: Hemiptera: Heteroptera). BMC Genomics 9: 610.

Jiang GF. 2000. Mitochondrial cytochrome b gene sequences and systematic evolutionary studies of Tetrigoidea. M.Sc. Thesis, Xi'an: Shaanxi Normal University.

Kearse M, Moir R, Wilson A, Stones-Havas S, Cheung M, Sturrock S, Buxton S, Cooper A, Markowitz S, Duran C, Thierer T, Ashton B, Meintjes P, Drummond A. 2012. Geneious Basic: an integrated and extendable desktop software platform for the organization and analysis of sequence data. Bioinformatics 28:1647-1649. 
Kim I, Cha SY, Yoon MH, Hwang JS, Lee SM, Sohn HD, Jin BR. 2005. The complete nucleotide sequence and gene organization of the mitochondrial genome of the oriental mole cricket, Gryllotalpa orientalis (Orthoptera: Gryllotalpidae). Gene 353:155-168.

Lanfear R, Calcott B, Ho SYW, Guindon S. 2012. PartitionFinder: Combined selection of partitioning schemes and substitution models for phylogenetic analysis. Molecular Biology and Evolution 29:16951701.

Leavitt JR, Hiatt KD, Whiting MF, Song H. 2013. Searching for the optimal data partitioning strategy in mitochondrial phylogenomics: A phylogeny of Acridoidea (Insecta: Orthoptera: Caelifera) as a case study. Molecular Phylogenetics and Evolution 67:494-508.

Li H, Liu H, Shi AM, Štys P, Zhou XG, Cai WZ. 2012. The complete mitochondrial genome and novel gene arrangement of the Unique-Headed Bug Stenopirates sp. (Hemiptera: Enicocephalidae). PLoS One 7: e29419.

Librado P, Rozas J. 2009. DnaSP v5: a software for comprehensive analysis of DNA polymorphism data. Bioinformatics 25:1451-1452.

Liu N, Huang Y. 2010. Complete mitochondrial genome sequence of Acrida cinerea (Acrididae: Orthoptera) and comparative analysis of mitochondrial genomes in Orthoptera. Comparative and Functional Genomics 2010:319486.

Lowe TM, Eddy SR. 1997. tRNAscan-SE: a program for improved detection of transfer RNA genes in genomic sequence. Nucleic Acids Research 25:955-964.

Ma EB, Guo YP. 1994. Study on the chromosomal C-banding karyotype of Criotettix bispinosus (Dalman,1818). Entomological research(No.1), Xi’an: Shaanxi Normal University Press pp.113-117.

Ma EB, Zheng L. 1994. The C-banding karyotype of Tetrix japonica (BOL.) (Orthoptera: Tetrigoidea). Journal of Shanxi University 17:445-448.

Maryańska-Nadachowska A, Warchałowska-Śliwa E. 1991. The B-chromosome in the karyotype of Tetrix tenuicornis (Sahlb.) (Tetrigidae: Orthoptera). Genetica 89:125-129.

Ojala D, Montoya J, Attardi G. 1981. tRNA punctuation model of RNA processing in Human mitochondria. Nature 290:470-474.

Paranjape SY, Bhalerao AM. 1985. Bioecological observations on a pigmy locust, Potua sabulosa Hancock (Tetrigidae: Orthoptera). Psyche 92:331-336.

Perna NT, Kocher TD. 1995. Patterns of nucleotide composition at fourfold degenerate sites of animal mitochondrial genomes. Journal of Molecular Evolution 41:353-358.

Rambaut A, Drummond A. 2004. Tracer. Published by the Authors. http://tree.bio.ed.ac.uk/software/tracer/

Rohde K, Hau Y, Weyer J, Hochkirch A. 2015. Wide prevalence of hybridization in two sympatric grasshopper species may be shaped by their relative abundances. BMC Evolutionary Biology 15:1-14.

Ronquist F, Huelsenbeck JP. 2003. MrBayes 3: Bayesian phylogenetic inference under mixed models. Bioinformatics 19:1572-1574.

Sambrook J. Russell DW. 2001. Molecular Cloning: A Laboratory Manual. New York: Cold Spring Harbor Laboratory Press.

Sheffield NC, Hiatt KD. Valentine MC, Song H, Whiting MF. 2010. Mitochondrial genomics in Orthoptera using MOSAS. Mitochondrial DNA 21:87-104.

Shuang-Shuang C, Wei-Wei Y, Meng S, Yu-Zhou D. 2014. Characterization of the complete mitochondrial 
genome of Tryporyza incertulas, in comparison with seven other Pyraloidea moths. Gene 533:356-365.

Simon C, Buckley TR, Frati F, Stewart JB, Beckenbach AT. 2006. Incorporating molecular evolution into phylogenetic analysis, and a new compilation of conserved polymerase chain reaction primers for animal mitochondrial DNA. Annual Review of Ecology, Evolution, and Systematics 37:545-579.

Song H, Amedegnato C, Cigliano MM, Desutter-Grandcolas L, Heads SW, Huang Y, Otte D, Whiting MF. 2015. 300 million years of diversification: elucidating the patterns of orthopteran evolution based on comprehensive taxon and gene sampling. Cladistics 31:621-65.

Staden R, Beal KF, Bonfield JK. 2000. The Staden package, 1998. Methods in Molecular Biology 132:115130.

Stamatakis A. 2006. RAxML-VI-HPC: maximum likelihood-based phylogenetic analyses with thousands of taxa and mixed models. Bioinform 22:2688-2690.

Tamura K, Stecher G, Peterson D, Filipski A, and Kumar S. 2013. MEGA6: Molecular Evolutionary Genetics Analysis Version 6.0. Molecular Biology and Evolution 30:2725-2729.

Tan MH, Gan HM, Lee YP, Poore GC, Austin CM. 2017. Digging deeper: new gene order rearrangements and distinct patterns of codons usage in mitochondrial genomes among shrimps from the Axiidea, Gebiidea and Caridea (Crustacea: Decapoda). PeerJ 5:e2982.

Thompson JD, Gibson TJ, Plewniak F, Jeanmougin F, Higgins DG. 1997. The CLUSTAL X Windows interface: flexible strategies for multiple sequence alignment aided by quality analysis tools. Nucleic Acids Research 25:4876-4882.

Warchałowska-Śliwa E, Maryańska-Nadachowska A. 1989. Karyology of Tetrix tenuicornis (Sahlb.) (Tetrigidae: Orthoptera). Folia biologica 37:45-54.

Wei SJ. 2009. Characteristic and evolution of Hymenoptera mitochondrial genome and its application in phylogentic research. Ph.D. Thesis, Xi'an: Shaanxi Normal University.

Yang F, Du YZ, Wang LP, Cao JM, Yu WW. 2011. The complete mitochondrial genome of the leafminer Liriomyza sativae (Diptera: Agromyzidae): Great difference in the A+T-rich region compared to Liriomyza trifolii. Gene 485:7-15.

Yao YP. 2008. Molecular evolution and phylogentic research of 16S and 18S rRNA gene sequences of some Tetrigoidea species in China. M. Sc. Thesis, Xi'an: Shaanxi Normal University.

Zeng HH. 2014. Sequencing and phylogentic analysis of four grasshopper mitochondrial genomes. Ph. D. Thesis, Xi' an: Shaanxi Normal University.

Zhang DX, Hewitt FM. 1997. Insect mitochondrial control region: a review of its structure, evolution and usefulness in evolutionary studies. Biochemical Systematics and Ecology 25:99-120.

Zhang DX, Szymura JM, Hewitt GM. 1995. Evolution and structural conservation of the control region of insect mitochondrial DNA. Journal of Molecular Evolution 40:382-391.

Zhang HL. 2013. Sequencing of four grasshopper mitochondrial genomes and comparative \& phylogentic analysis of Orthoptera. Ph. D. Thesis, Xi'an: Shaanxi Normal University.

Zhang HL, Huang Y, Lin LL, Wang XY, Zheng ZM. 2013a. The phylogeny of the Orthoptera (Insecta) as deduced from mitogenomic gene sequences. Zoological Studies 52:37.

Zhang HL, Zhao L, Zheng ZM, Huang Y. 2013b. Complete mitochondrial genome of Gomphocerus sibiricus (Orthoptera: Acrididae) and comparative analysis in four Gomphocerinae mitogenomes. Zoological Science 30:192-204. 
433

434

435

436

437

438

439

440

441

442

443

Zhang KJ, Zhu WC, Rong X, Liu J, Ding XL, Hong XY. 2014. The complete mitochondrial genome sequence of Sogatella furcifera (Horváth) and a comparative mitogenomic analysis of three predominant rice planthoppers. Gene 533:100-109.

Zheng ZM. 2007. Fauna of Tetrigoidea from Western China. Beijing: Science Press; 2005.

Zhao L, Zheng Z.M, Huang Y, Sun HM. 2010. A comparative analysis of mitochondrial genomes in Orthoptera (Arthropoda: Insecta) and genome descriptions of three grasshopper species. Zoological Studies 27:662-672.

Zhou ZJ. 2008. Sequencing of five long-horned grasshopper mitochondrial genomes and phylogenomic analysis of Orthoptera. Ph.D. Thesis, Xi'an: Shaanxi Normal University.

Zhou ZJ, Shi FM, Zhao L. 2014. The first mitochondrial genome for the superfamily Hagloidea and implications for its systematic status in Ensifera. PLoS One 9:e86027. 


\section{Table $\mathbf{1}$ (on next page)}

Table 1. The optimal partitions and best models for different data sets selected by using PartitionFinder v1.1.1.

Note: pos1: the first codon site of each PCG, pos2: the second codon site of each PCG, pos3: the third codon site of each PCG. 
1 Table 1 The optimal partitions and best models for different data sets selected by using PartitionFinder

2 v1.1.1. Note: pos1: the first codon site of each PCG, pos2: the second codon site of each PCG, pos3: the third 3 codon site of each PCG.

\begin{tabular}{|c|c|c|c|}
\hline Dataset & Partition & Optimal partitions & $\begin{array}{l}\text { Best } \\
\text { model }\end{array}$ \\
\hline \multirow[t]{5}{*}{ PCG12-ML } & $\mathrm{P} 1$ & atp8_pos1, nad2_pos1, nad6_pos1 & $\mathrm{GTR}+\mathrm{I}+\mathrm{G}$ \\
\hline & $\mathrm{P} 2$ & $\begin{array}{l}\text { atp6_pos1, cox1_pos1, cox2_pos1, cox3_pos1, cytb_pos1, } \\
\text { nad3_pos1 }\end{array}$ & $\mathrm{GTR}+\mathrm{I}+\mathrm{G}$ \\
\hline & $\mathrm{P} 3$ & nad1_pos1, nad4L_pos1, nad4_pos1, nad5_pos1 & $\mathrm{GTR}+\mathrm{I}+\mathrm{G}$ \\
\hline & P4 & $\begin{array}{l}\text { atp6_pos2, atp8_pos2, cox } 1 \_ \text {pos } 2, \operatorname{cox} 2 \_ \text {pos } 2, \operatorname{cox} 3 \_ \text {pos } 2, \\
\text { cytb_pos2, nad2 } 2 \text { pos } 2, \operatorname{nad} 3 \_ \text {pos } 2 \text {, nad } 6 \_ \text {pos } 2\end{array}$ & $\mathrm{GTR}+\mathrm{I}+\mathrm{G}$ \\
\hline & P5 & nad1_pos2, nad4L_pos2, nad4_pos2, nad5_pos2 & $\mathrm{GTR}+\mathrm{I}+\mathrm{G}$ \\
\hline \multirow[t]{5}{*}{ PCG12-BI } & $\mathrm{P} 1$ & atp8_pos1, nad2_pos1, nad6_pos1 & $\mathrm{GTR}+\mathrm{I}+\mathrm{G}$ \\
\hline & $\mathrm{P} 2$ & $\begin{array}{l}\text { atp6_pos1, cox1_pos1, cox } 2 \_ \text {pos } 1, \text { cox } 3 \_ \text {pos } 1 \text {, cytb_pos } 1 \text {, } \\
\text { nad3_pos1 }\end{array}$ & $\mathrm{GTR}+\mathrm{I}+\mathrm{G}$ \\
\hline & $\mathrm{P} 3$ & nad1_pos1, nad4L_pos1, nad4_pos1, nad5_pos1 & $\mathrm{GTR}+\mathrm{I}+\mathrm{G}$ \\
\hline & P4 & $\begin{array}{l}\text { atp6_pos2, atp8_pos2, cox1_pos2, cox } 2 \_ \text {pos } 2, \operatorname{cox} 3 \_ \text {pos } 2, \\
\text { cytb_pos2, nad2 } 2 \text { pos } 2, \operatorname{nad} 3 \_ \text {pos } 2, \operatorname{nad} 6 \_ \text {pos } 2\end{array}$ & $\mathrm{GTR}+\mathrm{I}+\mathrm{G}$ \\
\hline & P5 & nad1_pos2, nad4L_pos2, nad4_pos2, nad5_pos2 & $\mathrm{GTR}+\mathrm{I}+\mathrm{G}$ \\
\hline \multirow[t]{6}{*}{ PCG123RY-ML } & P1 & atp8_pos1, nad2_pos1, nad6_pos1, nad6_pos3 & $\mathrm{GTR}+\mathrm{G}$ \\
\hline & $\mathrm{P} 2$ & $\begin{array}{l}\text { atp6_pos1, cox1_pos1, cox2_pos1, cox3_pos1, cytb_pos1, } \\
\text { nad3_pos1 }\end{array}$ & $\mathrm{GTR}+\mathrm{I}+\mathrm{G}$ \\
\hline & P3 & nad1_pos1, nad4L_pos1, nad4_pos1, nad5_pos1 & $\mathrm{GTR}+\mathrm{I}+\mathrm{G}$ \\
\hline & $\mathrm{P} 4$ & $\begin{array}{l}\text { atp6_pos2, atp8_pos2, cox1_pos2, cox2_pos2, cox3_pos2, } \\
\text { cytb_pos2, nad2_pos2, nad3_pos2, nad6_pos } 2\end{array}$ & $\mathrm{GTR}+\mathrm{I}+\mathrm{G}$ \\
\hline & P5 & nad1_pos2, nad4L_pos2, nad4_pos2, nad5_pos2 & $\mathrm{GTR}+\mathrm{I}+\mathrm{G}$ \\
\hline & P6 & $\begin{array}{l}\text { atp6_pos3, atp8_pos3, cox1_pos3, cox2_pos3, cox3_pos3, } \\
\text { cytb_pos3, nad1_pos3, nad2_pos3, nad3_pos3, nad4L_pos3, } \\
\text { nad4_pos3, nad5_pos3 }\end{array}$ & $\mathrm{GTR}+\mathrm{G}$ \\
\hline \multirow[t]{6}{*}{ PCG123RY-BI } & $\mathrm{P} 1$ & $\begin{array}{l}\text { atp8_pos1, atp8_pos2, atp8_pos3, nad1_pos3, nad2_pos1, } \\
\text { nad2_pos3, nad4L_pos3, nad4_pos3, nad5_pos3, nad6_pos1, } \\
\text { nad6_pos3 }\end{array}$ & $\mathrm{GTR}+\mathrm{G}$ \\
\hline & $\mathrm{P} 2$ & $\begin{array}{l}\text { atp6_pos1, cox1_pos1, cox2_pos1, cox3_pos1, cytb_pos1, } \\
\text { nad3_pos1 }\end{array}$ & $\mathrm{GTR}+\mathrm{I}+\mathrm{G}$ \\
\hline & P3 & nad1_pos1, nad4L_pos1, nad4_pos1, nad5_pos1 & $\mathrm{GTR}+\mathrm{I}+\mathrm{G}$ \\
\hline & P4 & $\begin{array}{l}\text { atp6_pos2, cox1_pos2, cox } 2 \_ \text {pos } 2, \operatorname{cox} 3 \_ \text {pos } 2, \text { cytb_pos } 2, \\
\text { nad2_pos2, nad3_pos2, nad6_pos } 2\end{array}$ & $\mathrm{GTR}+\mathrm{I}+\mathrm{G}$ \\
\hline & P5 & nad1_pos2, nad4L_pos2, nad4_pos2, nad5_pos2 & $\mathrm{GTR}+\mathrm{I}+\mathrm{G}$ \\
\hline & P6 & $\begin{array}{l}\text { atp6_pos3, cox1_pos3, cox } 2 \_ \text {pos } 3 \text {, cox } 3 \_ \text {pos } 3 \text {, cytb_pos } 3 \text {, } \\
\text { nad3_pos3 }\end{array}$ & $\mathrm{SYM}+\mathrm{G}$ \\
\hline \multirow[t]{4}{*}{ PCG12+rRNA-ML } & $\mathrm{P} 1$ & atp8_pos1, nad2_pos1, nad6_pos1 & $\mathrm{GTR}+\mathrm{I}+\mathrm{G}$ \\
\hline & $\mathrm{P} 2$ & $\begin{array}{l}\text { atp6_pos1, cox1_pos1, cox2_pos1, cox3_pos1, cytb_pos1, } \\
\text { nad3_pos1 }\end{array}$ & $\mathrm{GTR}+\mathrm{I}+\mathrm{G}$ \\
\hline & P3 & nad1_pos1, nad4L_pos1, nad4_pos1, nad5_pos1, rrnL, rrnS & $\mathrm{GTR}+\mathrm{I}+\mathrm{G}$ \\
\hline & P4 & atp6 6 pos2, atp8_pos2, cox1_pos2, cox2_pos2, cox3_pos2, & $\mathrm{GTR}+\mathrm{I}+\mathrm{G}$ \\
\hline
\end{tabular}




\begin{tabular}{|c|c|c|c|}
\hline & & cytb_pos2, nad2_pos2, nad3_pos2, nad6_pos2 & \\
\hline & P5 & nad1_pos2, nad4L_pos2, nad4_pos2, nad5_pos2 & $\mathrm{GTR}+\mathrm{I}+\mathrm{G}$ \\
\hline \multirow[t]{5}{*}{ PCG12+rRNA-BI } & P1 & atp8_pos1, atp8_pos2, nad2_pos1, nad6_pos 1 & $\mathrm{GTR}+\mathrm{G}$ \\
\hline & $\mathrm{P} 2$ & $\begin{array}{l}\text { atp6_pos1, cox1_pos1, cox2_pos1, cox3_pos1, cytb_pos1, } \\
\text { nad3_pos } 1\end{array}$ & $\mathrm{GTR}+\mathrm{I}+\mathrm{G}$ \\
\hline & P3 & nad1_pos1, nad4L_pos1, nad4_pos1, nad5_pos1, rrnL, rrnS & $\mathrm{GTR}+\mathrm{I}+\mathrm{G}$ \\
\hline & P4 & $\begin{array}{l}\text { atp6_pos2, cox } 1 \_ \text {pos } 2, \operatorname{cox} 2 \_ \text {pos } 2, \operatorname{cox} 3 \_ \text {pos } 2, \text { cytb_pos } 2 \text {, } \\
\text { nad2_pos2, nad3_pos2, nad6_pos } 2\end{array}$ & $\mathrm{GTR}+\mathrm{I}+\mathrm{G}$ \\
\hline & P5 & nad1_pos2, nad4L_pos2, nad4_pos2, nad5_pos2 & $\mathrm{GTR}+\mathrm{I}+\mathrm{G}$ \\
\hline \multirow[t]{5}{*}{$\begin{array}{l}\text { PCG123RY+rRNA- } \\
\text { ML }\end{array}$} & $\mathrm{P} 1$ & 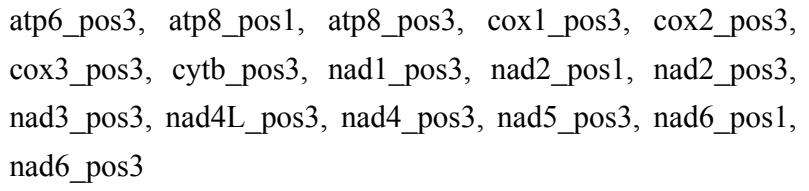 & $\mathrm{GTR}+\mathrm{G}$ \\
\hline & $\mathrm{P} 2$ & $\begin{array}{l}\text { atp6_pos1, cox1_pos1, cox2_pos1, cox3_pos1, cytb_pos1, } \\
\text { nad3_pos1 }\end{array}$ & $\mathrm{GTR}+\mathrm{I}+\mathrm{G}$ \\
\hline & P3 & nad1_pos1, nad4L_pos1, nad4_pos1, nad5_pos1, rrnL, rrnS & $\mathrm{GTR}+\mathrm{I}+\mathrm{G}$ \\
\hline & P4 & $\begin{array}{l}\text { atp6_pos2, atp } 8 \_ \text {pos } 2, \operatorname{cox} 1 \_ \text {pos } 2, \operatorname{cox} 2 \_ \text {pos } 2, \operatorname{cox} 3 \_ \text {pos } 2, \\
\text { cytb_pos2, nad2 } \_ \text {pos } 2, \operatorname{nad} 3 \_ \text {pos } 2, \operatorname{nad} 6 \_ \text {pos } 2\end{array}$ & $\mathrm{GTR}+\mathrm{I}+\mathrm{G}$ \\
\hline & P5 & nad1_pos2, nad4L_pos2, nad4_pos2, nad5_pos2 & $\mathrm{GTR}+\mathrm{I}+\mathrm{G}$ \\
\hline \multirow[t]{6}{*}{ PCG123RY+rRNA-BI } & P1 & $\begin{array}{l}\text { atp8_pos1, atp8_pos2, atp8_pos3, nad1_pos3, nad2_pos1, } \\
\text { nad2_pos3, nad3_pos3, nad4L_pos3, nad4_pos3, nad5_pos3, } \\
\text { nad6_pos1, nad6_pos3 }\end{array}$ & $\mathrm{GTR}+\mathrm{G}$ \\
\hline & $\mathrm{P} 2$ & $\begin{array}{l}\text { atp6_pos1, cox1_pos1, cox2_pos1, cox3_pos1, cytb_pos1, } \\
\text { nad3_pos1 }\end{array}$ & $\mathrm{GTR}+\mathrm{I}+\mathrm{G}$ \\
\hline & $\mathrm{P} 3$ & nad1_pos1, nad4L_pos1, nad4_pos1, nad5_pos1, rrnL, rrnS & $\mathrm{GTR}+\mathrm{I}+\mathrm{G}$ \\
\hline & P4 & 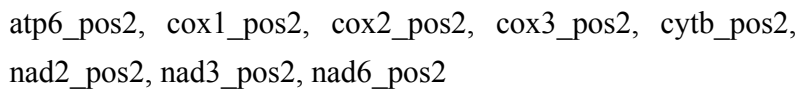 & $\mathrm{GTR}+\mathrm{I}+\mathrm{G}$ \\
\hline & P5 & nad1_pos2, nad4L_pos2, nad4_pos2, nad5_pos2 & $\mathrm{GTR}+\mathrm{I}+\mathrm{G}$ \\
\hline & P6 & atp6 6 pos3, cox $1 \_$pos $3, \operatorname{cox} 2 \_$pos $3, \operatorname{cox} 3$ _pos 3, cytb_pos 3 & $\mathrm{SYM}+\mathrm{G}$ \\
\hline
\end{tabular}




\section{Table 2 (on next page)}

Table 2. Annotation of the mitochondrial genomes of Formosatettix qinlingensis (F. q), Coptotettix longjiangensis (C. I) and Thoradonta obtusilobata (T. o). 
1 Table 2 Annotation of the mitochondrial genomes of Formosatettix qinlingensis (F. q), Coptotettix 2 longjiangensis (C. I) and Thoradonta obtusilobata (T. o).

\begin{tabular}{|c|c|c|c|c|c|c|c|}
\hline \multirow{2}{*}{ Feature } & \multirow{2}{*}{ Strand } & \multicolumn{3}{|c|}{ Position } & \multicolumn{3}{|c|}{ Initiation codon/Stop codon } \\
\hline & & F. q & C. 1 & T. o & F. q & C. 1 & T. o \\
\hline $\operatorname{trnI}$ & $\mathrm{J}$ & $<1-54$ & $<1-25$ & & & & \\
\hline $\operatorname{trnQ}$ & $\mathrm{N}$ & $55-123$ & $27-95$ & & & & \\
\hline $\operatorname{trnM}$ & $\mathrm{J}$ & 123-191 & $95-163$ & $<1-17$ & & & \\
\hline nad2 & $\mathrm{J}$ & $192-1,193$ & $164-1,165$ & $18-1,028$ & ATG/TAA & GTG/TAA & ATT/TAA \\
\hline $\operatorname{trnW}$ & $\mathrm{J}$ & $1,192-1,257$ & $1,169-1,234$ & $1,027-1,092$ & & & \\
\hline $\operatorname{trnC}$ & $\mathrm{N}$ & $1,250-1,315$ & $1,227-1,291$ & $1,085-1,146$ & & & \\
\hline $\operatorname{trn} Y$ & $\mathrm{~N}$ & $1,316-1,379$ & $1,294-1,358$ & $1,147-1,212$ & & & \\
\hline $\operatorname{cox} 1$ & $\mathrm{~J}$ & $1,377-2,915$ & $1,356-2,894$ & $1,210-2,748$ & ATC/TAA & ATC/TAA & ATC/TAG \\
\hline $\operatorname{trnL}$ (uur) & $\mathrm{J}$ & $2,911-2,974$ & $2,890-2,953$ & $2,744-2,806$ & & & \\
\hline $\operatorname{cox} 2$ & $\mathrm{~J}$ & $2,975-3,658$ & $2,954-3,637$ & $2,807-3,484$ & ATG/TAA & ATG/TAA & ATG/TAA \\
\hline $\operatorname{trn} \mathrm{D}$ & $\mathrm{J}$ & $3,657-3,719$ & $3,636-3,700$ & $3,483-3,545$ & & & \\
\hline $\operatorname{trnK}$ & $\mathrm{J}$ & $3,720-3,787$ & $3,701-3,772$ & $3,546-3,611$ & & & \\
\hline atp8 & $\mathrm{J}$ & $3,792-3,947$ & $3,776-3,934$ & $3,612-3,764$ & ATG/TAA & ATG/TAA & ATG/TAA \\
\hline atp6 & $\mathrm{J}$ & $3,941-4,612$ & $3,934-4,605$ & $3,758-4,429$ & ATG/TAA & ATG/TAA & ATG/TAA \\
\hline $\operatorname{cox} 3$ & $\mathrm{~J}$ & $4,612-5,401$ & $4,605-5,394$ & $4,429-5,218$ & ATG/T & ATG/T & ATG/T \\
\hline $\operatorname{trnG}$ & $\mathrm{J}$ & $5,402-5,464$ & $5,396-5,461$ & $5,220-5,281$ & & & \\
\hline $\operatorname{nad} 3$ & $\mathrm{~J}$ & $5,462-5,818$ & $5,459-5,815$ & $5,279-5,635$ & ATT/TAG & ATA/TAG & ATA/TAG \\
\hline $\operatorname{trn} \mathrm{A}$ & $\mathrm{J}$ & $5,817-5,881$ & $5,814-5,878$ & $5,634-5,696$ & & & \\
\hline $\operatorname{trn} R$ & $\mathrm{~J}$ & $5,881-5,943$ & $5,878-5,942$ & $5,696-5,758$ & & & \\
\hline $\operatorname{trnN}$ & $\mathrm{J}$ & $5,940-6,003$ & $5,939-6,002$ & $5,751-5,814$ & & & \\
\hline $\operatorname{trnS(agn)}$ & $\mathrm{J}$ & $6,003-6,071$ & $6,002-6,070$ & $5,814-5,882$ & & & \\
\hline $\operatorname{trnE}$ & $\mathrm{J}$ & $6,071-6,134$ & $6,070-6,132$ & $5,882-5,944$ & & & \\
\hline $\operatorname{trnF}$ & $\mathrm{N}$ & 6,133-6,195 & 6,131-6,193 & $5,943-6,005$ & & & \\
\hline nad5 & $\mathrm{N}$ & $6,199-7,915$ & $6,194-7,910$ & $6,009-7,722$ & $\mathrm{ATG} / \mathrm{T}$ & ATG/T & ATG/T \\
\hline $\operatorname{trnH}$ & $\mathrm{N}$ & 7,919-7,982 & $7,914-7,977$ & $7,724-7,785$ & & & \\
\hline nad4 & $\mathrm{N}$ & $7,982-9,307$ & $7,977-9,302$ & $7,785-9,110$ & ATG/TAG & ATG/TAG & ATG/TAG \\
\hline $\operatorname{nad} 4 \mathrm{~L}$ & $\mathrm{~N}$ & $9,301-9,591$ & 9,296-9,586 & $9,104-9,388$ & ATT/TAA & ATT/TAA & ATT/TAA \\
\hline $\operatorname{trn} \mathrm{T}$ & $\mathrm{J}$ & $9,594-9,658$ & $9,589-9,653$ & $9,391-9,452$ & & & \\
\hline $\operatorname{trnP}$ & $\mathrm{N}$ & $9,659-9,722$ & $9,654-9,717$ & $9,453-9,517$ & & & \\
\hline nad6 & $\mathrm{J}$ & $9,724-10,218$ & $9,719-10,216$ & $9,519-10,013$ & ATG/TAA & ATG/TAA & TTG/TAA \\
\hline cytb & $\mathrm{J}$ & $10,218-11,354$ & $10,216-11,352$ & $10,013-11,149$ & ATG/TAG & ATG/TAA & ATG/TAA \\
\hline $\operatorname{trnS}(u c n)$ & $\mathrm{J}$ & $11,353-11,420$ & $11,366-11,433$ & $11,148-11,214$ & & & \\
\hline nad1 & $\mathrm{N}$ & $11,433-12,377$ & $11,565-12,509$ & $11,614-12,564$ & ATA/TAA & GTA/TAA & ACA/TAA \\
\hline $\operatorname{trnL}$ (cun) & $\mathrm{N}$ & $12,372-12,434$ & $12,504-12,565$ & $12,559-12,623$ & & & \\
\hline $\mathrm{rrnL}$ & $\mathrm{N}$ & $12,435-13,726$ & $12,566-13,858$ & $12,625-13,909$ & & & \\
\hline $\operatorname{trnV}$ & $\mathrm{N}$ & $13,728-13,799$ & $13,861-13,932$ & $13,910-13,980$ & & & \\
\hline $\mathrm{rrnS}$ & $\mathrm{N}$ & $13,800-14,580$ & $13,933->14,495$ & $13,981->14,538$ & & & \\
\hline $\mathrm{A}+\mathrm{T}$-rich region & & $14,581 \sim 15,180$ & & & & & \\
\hline
\end{tabular}


Figure 1

Figure 1. Mitochondrial map of three Tetrigoidea species (Formosatettix qinlingensis, Coptotettix longjiangensis and Thoradonta obtusilobata).

Note: * means partial or not sequenced genes.

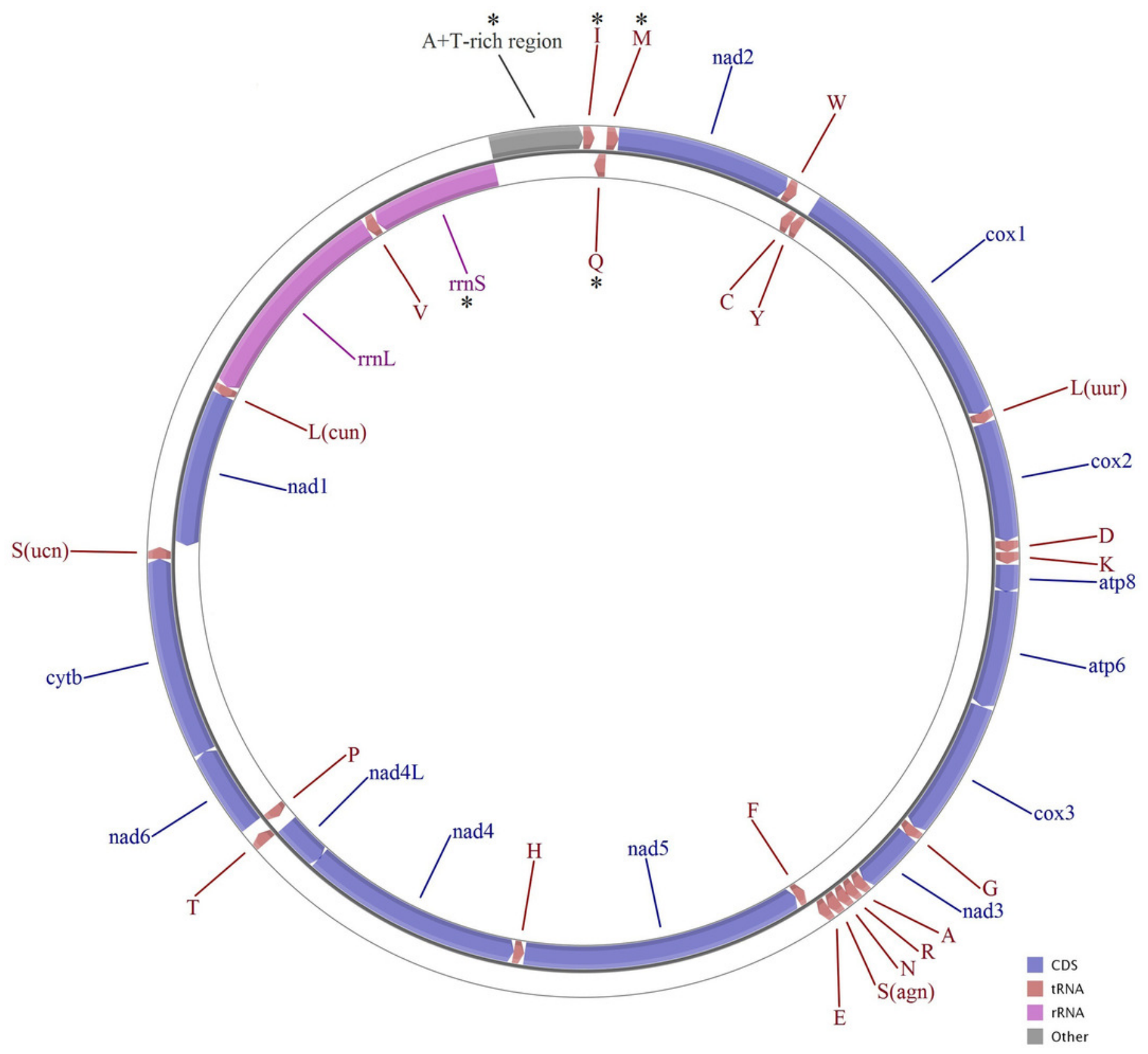


Figure 2

Figure 2. The A+T content vs AT-skew and G+C content vs GC-skew in Caelifera mitogenomes. 


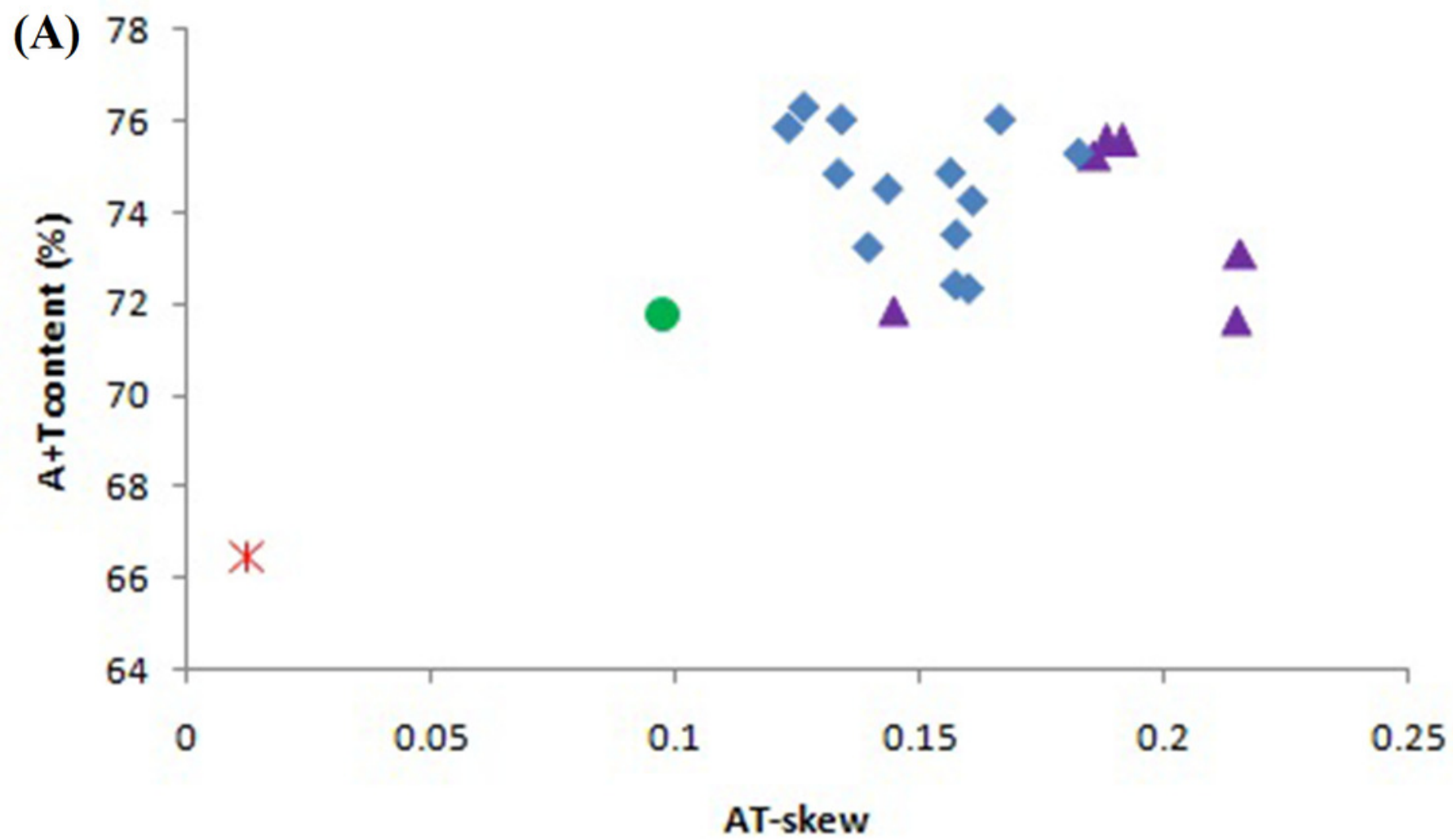

(B)

*

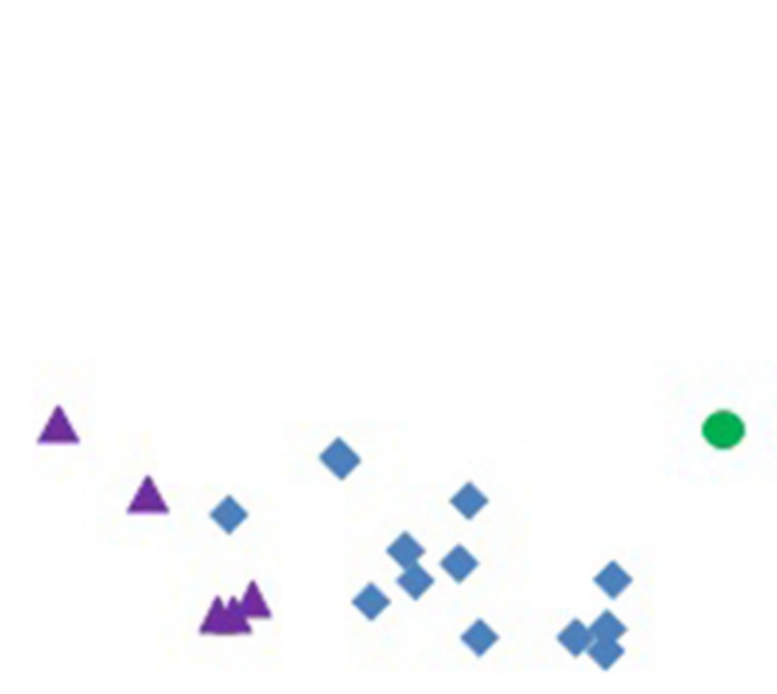

GC-skew

* Tridactyloidea Eumastacoidea $\Delta$ Tetrigoidea Acridoidea 
Figure 3

Figure 3. Alignments of the intergenic spacer between $\operatorname{trnS}(\mathrm{UCN})$ and nad1 genes in caeliferan mitogenomes 


\section{(A) Tetrigoidea}

Alulatettix yunnanensis

Trachytettix bufo

Formosatettix qinlingensis

Coptotettix longjiangensis

Tetrix japonica

Thoradonta obtusilobata
TTCTATTTTTTACTTTTCTAATTTTTAT TTCTATTTTTTAATTTTCTATTTTTTATTCTATTTTTA-

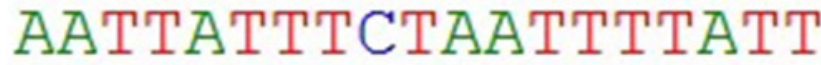

\section{(B) Acridoidea}

Acrida cinerea

Ceracris kiangsu

Oxya chinensis

Mekongiella xizangensis

Filchnerella helanshanensis

Pseudotmethis rubimarginis

Calliptamus italicus

Atractomorpha sinensis

Traulia szetschuanensis

Arcyptera coreana

Locusta migratoria

Prumna arctica

Gomphocerus sibiricus
ТААААТТСТААААААААТТААС GTTCTAAAAATAATTAATTCTAT - TCTAAAAAAATTTAATAGTTATTCTTAAAAAATTTCACTATTGTATTTCTGAAAAAATTTCACTATTGTATTTCTGAAAAAATTTCA TTTAATTCTCAAAAAATTTCATTCTCAAAAAATTTCAGTAAATTCTTAAAAAATTTCAATAAATTCTAAAAAAATTTAATTAAATTCTTAAA--АТTTAAATTAATTCTAGAAAAATTTCAATTATTTCTAGAAAAATTTCA-

\section{(C) Eumastacoidea}

Pielomastax zhengi AATTGTCTTGTTTATTGA

\section{(D) Tridactyloidea}

Ellipes minuta

TGTACAAAATTTATTTCA 
Figure 4

Figure 4. The $\mathrm{Ka} / \mathrm{Ks}$ values of atp8 gene with paired comparison in six Tetrigidae mitogenomes.

Note: A.y: Alulatettix yunnanensis, T.j: Tetrix japonica, T.b: Trachytettix bufo, F.q:

Formosatettix qinlingensis, C.I: Coptotettix longjiangensis, T.o: Thoradonta obtusilobata.

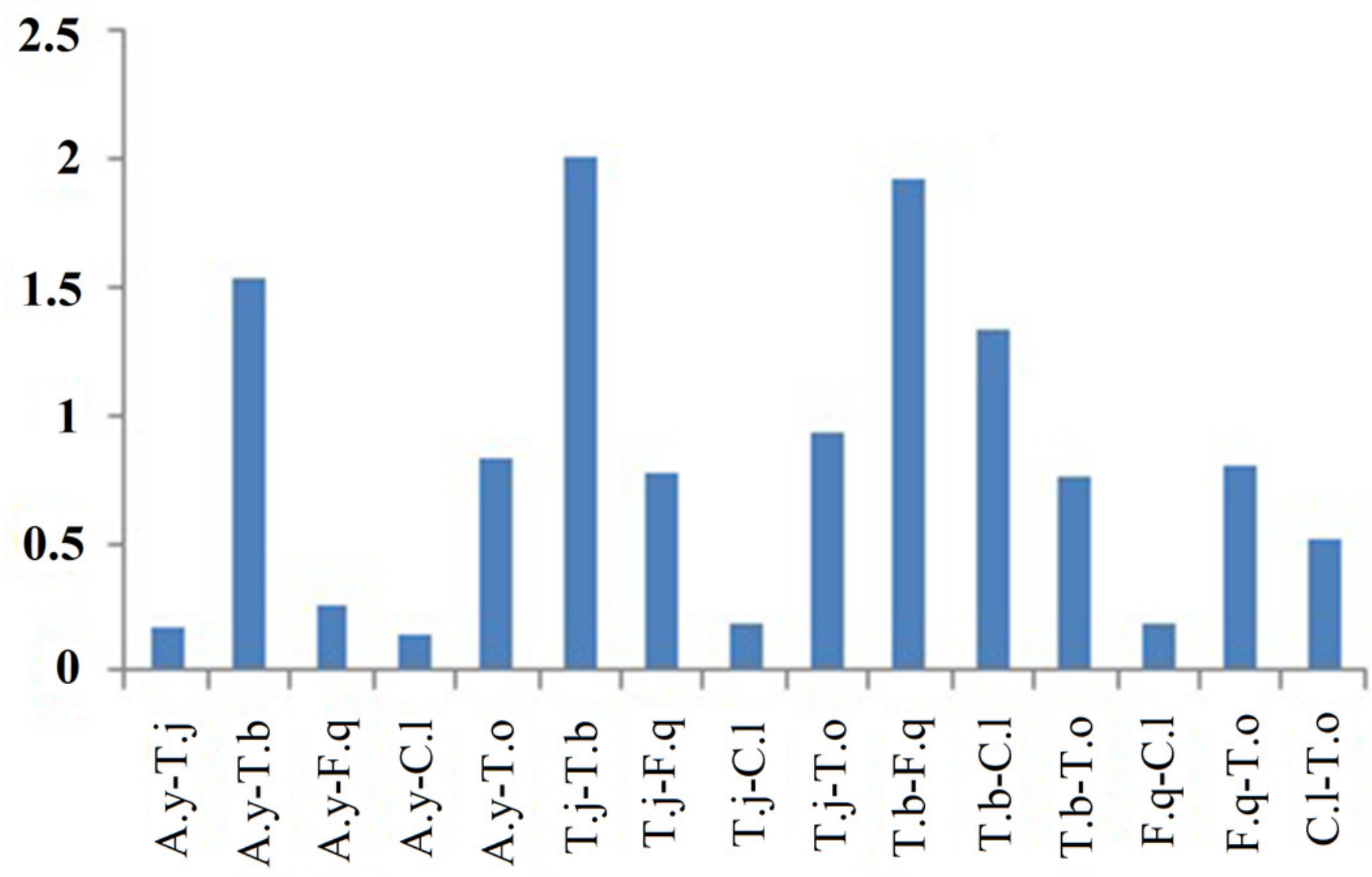




\section{Figure 5}

Figure 5. The varied amino acid and corresponding nucleotide sequences of atp8 gene in five Tetrigidae mitogenomes.

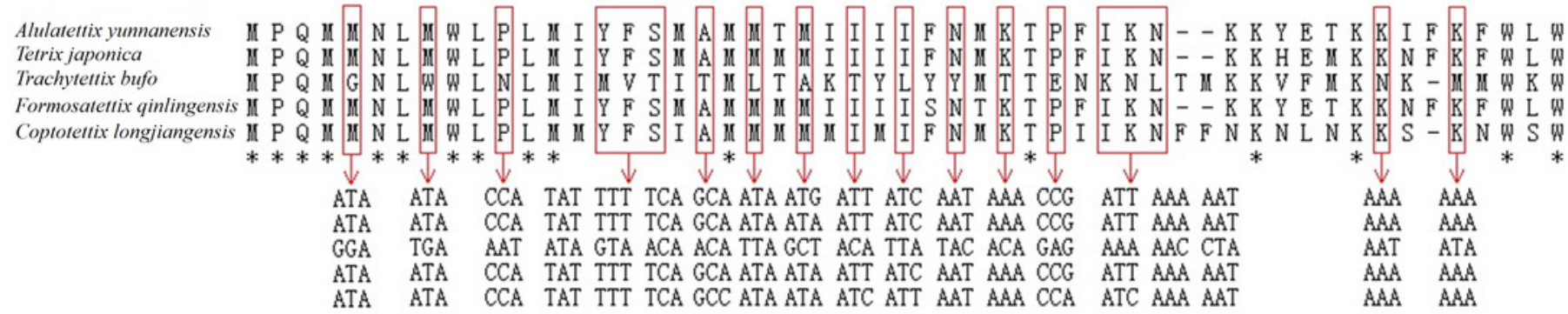


Figure 6

Figure 6. Phylogenetic reconstructions of some Caelifera species based on different datasets and methods.

Notes: Node supports from left to right above lines are the results of ML trees of PCG12, PCG123RY, PCG12rRNA and PCG123RYrRNA datasets, under lines are BI trees of PCG12, PCG123RY, PCG12rRNA and PCG123RYrRNA datasets, respectively. *: bootstrap support of 100 in ML trees or Bayesian posterial probability of 1.00 in BI trees. -: no support for the clade.

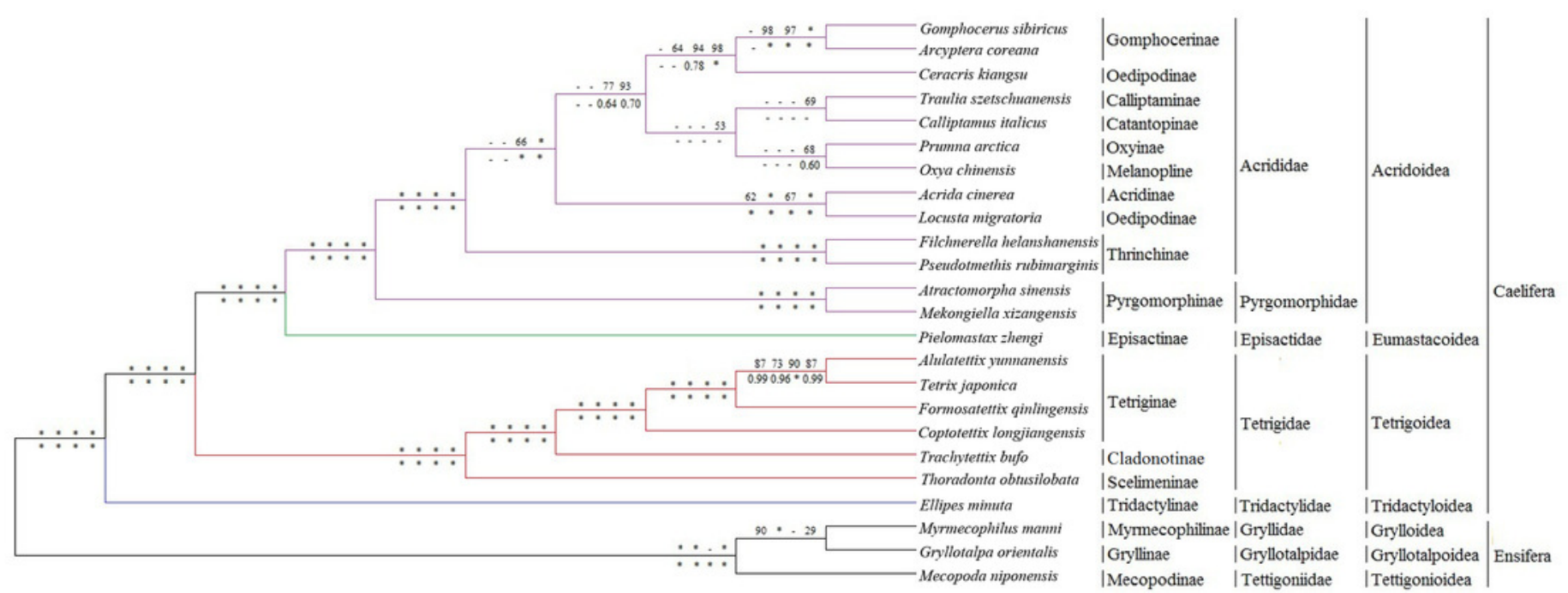

